New Zealand journal of industrial relations, 1987, 12, 199-201

\title{
Compulsory arbitration: the next 40 years
}

\author{
Peter Franks*
}

This comment argues that there must be a follow-up study to James Holt's Compulsory arbitration in New Zealand - the first forty years and examines three issues important to any such study: the formation of new unions after 1936; the way the arbitration system has protected vulnerable groups of workers; and women's wages and equal pay.

Compulsory arbitration in New Zealand - the first forty years is an oustanding contribution to labour history in this country. In my opinion, the most striking thing about James Holt's book is its relevance to today's debates about the labour market and industrial relations. The quality of those debates, and more importantly the legislative outcome, would have been greatly improved if more of the participants had actually taken account of the historical experience of the arbitration system in New Zealand.

At the recent Labour History symposium on Holt's book, I raised a laugh when I pointed out that the zealots of the Business Roundtable have taken their prescriptions for 'labour market flexibility' from experience in Japan and the southern United States not New Zealand. However it is no joke for working people who will have to bear the consequences. Holt's book shows how ironic it is that the leaders of the Business Roundtable, and those of the Employers Federation, claim to have based their recent programmes on overseas experience. In large part their prescriptions for 'reform' merely echo the views of employer representatives in past economic downturns in New Zealand, particularly during the Great Depression.

The best tribute that historians could pay to Holt would be to ensure that the sequel to his book is written, covering the final forty years of the Industrial Conciliation and Arbitration (IC\&A) Act. The purpose of this comment is to point out some of the issues that will need to be addressed in that sequel. These issues arise from my research in to the history of the Clerical Workers Union.

After its sweeping election victory in 1935, the first Labour Government introduced major changes to the IC\&A Act and other laws affecting workers. These included the restoration of compulsory arbitration, the registration of national unions, the introduction of the 40-hour week and compulsory unionism. One of the main results of these reforms was that the membership of private sector unions more than trebled from 80,929 in December 1935 to 254,690 in December 1939, while the number of awards increased by over $40 \%$ from 417 in March 1936 to 598 in March 1938(Hare, 1946). Several groups of workers which had never been effectively organised formed unions, of which clerical workers were the largest.

Fifty years on it is very easy to assume that the consequences of the introduction of compulsory unionism were a very mechanical process and I have often heard people describe unions like the Clerical Workers as 'creatures of legislation'. Although a sympathetic government and legislation encouraging unionisation were extremely important factors, a study of what happened during the early years of the first Labour Government shows that the process of unionising unorganised workers was anything but mechanical.

Labour Department files held in the National Archives show that after the amendments to the IC\&A Act were passed in early 1936, the Minister of Labour. Tim Armstrong. and his department were flooded with inquiries from workers and other groups about forming unions. For example, domestic workers, dental nurses in private practice, life agents, Maori guides at 
Whakarewarewa and staff of the Blind Institutes wanted to form unions while the Women's Division of the Farmers Union (now Federated Farmers) were interested in a union for housekeepers on farms (Labour Department, 1936). Many of the unorganised groups were women workers and there was initially no great expectation that they would form unions. Shortly after the 1935 election. Armstrong spoke of 'fixing wages by statute, with special reference to domestic and female office employees, who are unlikely to organise... (Tomorrow, 1935). However a number of officials of established unions were awake to the importance of unionising unorganised workers. In the first half of 1936 Clerical Workers Unions were formed in most industrial districts through the combined efforts of these men and of a small band of women office workers.

It took the Clerical Workers Unions almost two years to get established on a viable basis. During this time they faced determined opposition from employers who were generally appalled at the idea of office of office workers being unionised. Employer opposition included attempts to form company and industry clerical unions which they controlled, a challenge in the Court of Appeal against the legality of forming occupationally-based unions and moves to overth row the leadership of the Clerical Workers Unions and replace it with workers sympathetic to the employers. (Franks, 1986).

The point I am making is that the actual history of the formation of new unions after the 1936 reforms to the IC\&A Act was a far more uncertain process than one might assume from hindsight, and is something that deserves careful study.

Another important issue that should be examined is the way in which the arbitration system operated to protect the position of vulnerable groups in the workforce. Clerical workers are one such group. At the time the Clerical Workers Unions were formed there were many reports in the press about the low wages and bad conditions of many office workers (Franks, 1986). Once the unions achieved their first awards they were able to use the system to establish minimum wages and conditions for clerical workers throughout industry. Although the employers consistently tried to downgrade the value of clerical workers and their wages, the crucial thing that enabled the union to continue to maintain these standards was the Arbitration Court's policy of establishing and maintaining wages relativities between different occupations.

In the first multi-district Clerical Workers Award issued in July 1938, the Arbitration Court set the minimum wage for male clerks over 21 years of age at the same rate it had established for skilled workers in its Standard Wage Pronouncement of the previous year. The Court followed this relativity with remarkable consistency down the years; for example, following its 1945 and 1952 Standard Wage Pronouncements and its ruling in the 1966 'margins for skill' case in the Printing Trades Award, it set the top award wage for male clerical workers at the same level as, or slightly less than, the general rate it set for skilled male workers (NZ Clerical Workers Association, 1986). In 1971 the Court upheld the traditional relativity between clerical workers and tradesmen and granted clerical workers a 16 percent award rise, thereby causing a major upset in the wage controls imposed by the National Government of the day (Walsh, 1984). Finally, in 1977, the last time the main clerical workers' award went to arbitration, the Industrial Commission again upheld the traditional relativity (NZ Clerical Workers Association, 1986).

The clerical workers' traditional relativity was, to course, between the wages paid to male clerks and male tradesmen. However the great majority of clerical workers are, and always have been, women and the final issue I want to discuss here is that of women's wages. Unfortunately it is one that is largely ignored in Holt's book, as it is in other studies of wages policy in New Zealand.

One of the few studies to consider this question from an historical perspective is a recent one by Sue Iverson. She makes the point that relativities (both within and between awards) have had two effects in terms of women's pay. First, relativities have worked to a large degree in women's favour by maintaining their wages at a reasonable level. However, second, relativities have also preserved the inequalities that existed at the time that awards and relativities were first established (Iverson, 1986).

The Arbitration Court was not inclined to redress these inequalities, as its attitude to equal pay shows. Unions first started to raise equal pay claims during and immediately after the Second World War (which saw a big increase in the proportion of women in the workforce), and in 1949 the Clerical Workers Association took a major equal pay case to the Court. The Court had no enthusiasm for equal pay: the Judge made it clear that he considered the union's claim for one scale for women and men as being quite foreign to established wage-fixing principles (Moynihan, 1986). 
From that time until the Equal Pay Act was passed in 1972, the Court failed to address claims for equal pay, refusing even to comment on the issue. To make matters worse, the standard response of politicians on the issue was to tell unions that if they wanted equal pay they should negotiate it with employers or take their claims to the Court!

The frustration which these attitudes caused can be seen from the following union comment after the Clerical Workers Award went to arbitration in 1986:

Female workers have no reason to be happy about Mr Holyoake, Mr Marshall or the Arbitration Court. They are getting what is usually known as the 'run around' on equal pay. Mr Holyoake and Mr Marshall told us to apply to the Arbitration Court for equal pay. We therefore went to the Court and went again. We do not know whether the Court even considered our claims, it certainly didn t do anything to grant them ... Believe it or not even this plea for a comment by the Court made on behalf of 30.000 clerical workers fell upon apparently deaf ears. We accept the principle of arbitration. We therefore accept the Court's right to reject our claims or to grant them in part only. But when the Court, under the circumstances, meets us with a wall of silence it is destroying our faith in arbitration (Clerical News, 1967).

The Court's performance on equal pay did not improve even after the 1972 Equal Pay Act was passed. In her analysis of a number of equal pay cases dealt with by the Court between 1972 and 1986, Elizabeth Orr concludes that the Court registered a number of agreements which did not fully comply with the Act, failed to provide adequate guidelines in Section 9 of the 1972 Act and that it generally interpreted the Act in a restrictive manner so that equal pay legislation would be unlikely to be implemented satisfactorily under its jurisdiction (Orr. 1986).

This comment has touched on only a few of the issue that should be addressed in any follow-up study to James Holt's book. I hope that historians will take up the challenge to continue his excellent work; if the sequel is as good as the first instalment it can only be of benefit to all the participants in today's debates about the future of industrial relations.

\section{References}

Clerical News, (1967) March.

Franks $\mathrm{P}$ (1986) Nothing to lose but our gains - 50th anniversary of the founding of the Wellington, Taranaki. Marlborough and Nelson Clerical Workers Union unpublished address to the Union's annual conference.

Hare A E C (1946) Report on industrial relations in New Zealand Wellington.

Iverson Sue (1987) Why women get paid less Broadsheet January/February.

Labour Department file 3/2/1020 Part 1. 1936 - 1938. National Archives.

Moynihan Carolyn (1986) On your side - a history of the Northern Clerical, Administrative and Related Workers Union, 1936-1986 Auckland.

NZClerical Workers Association (1986) Submissions to the Arbitration Court on equal pay and the Equal Pay Act 1972 Wellington NZ Clerical Workers Association.

Orr E (1986) The Arbitration Court's role in supervising the Equal Pay Act 1972, Centre for Continuing Education, Victoria University.

Tomorrow (1935) 18 December.

Walsh Patrick J (1986) The rejection of corporatism: trade unions, employers and the state in New Zealand Ph.D Thesis, University of Minnesota. 